\title{
Indirect selection of industrial tomato genotypes rich in zingiberene and resistant to Tuta absoluta Meyrick
}

\author{
I.P. Lima', J.T.V. Resende ${ }^{2}$, J.R.F. Oliveira ${ }^{2}$, M.V. Faria ${ }^{2}$, N.C.V. Resende ${ }^{1}$ and \\ R.B. Lima Filho ${ }^{2}$ \\ 1Departamento de Agricultura, Universidade Federal de Lavras, Lavras, MG, Brasil \\ ${ }^{2}$ Departamento de Agronomia, Universidade Estadual do Centro-Oeste, \\ Campus Cedeteg, Guarapuava, PR, Brasil \\ Corresponding author: J.T.V. Resende \\ E-mail: jresende@unicentro.br / jvresende@uol.com.br \\ Genet. Mol. Res. 14 (4): 15081-15089 (2015) \\ Received June 15, 2015 \\ Accepted August 28, 2015 \\ Published November 24, 2015 \\ DOI http://dx.doi.org/10.4238/2015.November.24.16
}

ABSTRACT. Obtaining tomato cultivars resistant to pests through interspecific crosses between commercial cultivars and wild accessions is an important tool in integrated pest management. The aim of this study was to select tomato genotypes with high zingiberene (ZGB) levels that are resistant to the South American tomato moth (Tuta absoluta Meyrick) and to estimate genetic parameters of ZGB inheritance from the interspecific cross Solanum lycopersicum cultivar 'Redenção' x Solanum habrochaites var. hirsutum (PI-127826 accession). $F_{2}$ plants with different ZGB contents were selected and submitted to a tomato moth resistance test. ZGB content exhibits high broad sense heritability, with incomplete dominance of lower ZGB content. Furthermore, the level of ZGB in leaflets was estimated to be controlled by two genes. These results show that high ZGB levels are effective at conferring resistance to the South American tomato moth.

Key words: Solanum lycopersicum; Solanum habrochaites; Tuta absoluta; Allelochemicals; Pest resistance 


\section{INTRODUCTION}

Tomatoes (Solanum lycopersicum) used in industrial processing are cultivated in almost all Brazilian regions. Around 21,300 hectares are cultivated, with production of 1.87 million tons. Brazil is the world's fifth largest producer of tomatoes, accounting for nearly $5 \%$ of the total world production, which has great economic and social importance (Clemente and Boiteux, 2012).

Tomatoes are cultivated year-round; however, in warmer and rainy seasons, the yield is lower and the prices are higher. Variation in yield and price is related to the occurrence of arthropod pests and diseases, which cause great losses and increase the production costs with higher spending on chemical control (Clemente and Boiteux, 2012).

Tomatoes are one of the most important vegetables grown; however, they suffer many phytosanitary issues (Suinaga et al., 2003) including attacks from pests such as the South American tomato moth (Tuta absoluta Meyrick), which cause serious damage to tplant and fruits (Silva and Carvalho, 2004). Chemical sprays represent the main management method employed to control pests in tomato crops. The use of chemicals may cause severe damage to the environment, biological unbalancing, and damage to consumers and workers' health, besides incurring high production costs, of which the use of insecticides represents around $8.1 \%$ of the total (FAEG, 2013).

With increased demand for tomato based products by the consumer, as well as increased demand for high quality products with low agrochemical indexes, alternative methods of control have been used in an attempt to reduce the use of chemical products; this includes the use of resistant genotypes, which have shown promise in the fight against arthropod pests (Resende et al., 2009; Silva et al., 2009; Oliveira et al., 2012; Dias et al., 2013; Neiva et al., 2013; Lucini et al., 2015).

Zingiberene (ZGB) is an allelochemical present in type VI and IV glandular trichomes, which are found in leaflets of wild Solanum habrochaites var hirsutum (Gonçalves et al., 2006). In general, the selection of tomato genotypes with a high ZGB content has led to promising results by increasing resistance to arthropod pests such as the silverleaf whitefly (Bemisia tabaci Gennadius B biotype), the South American tomato moth (Tuta absoluta), and mites (Tetranychus spp) (Maluf et al., 2007; Silva et al., 2009; Oliveira et al., 2012; Neiva et al., 2013).

Thus, this study aimed to select plants that have a high ZGB content and show resistance to the tomato moth and which originated from the interspecific cross of Solanum lycopersicum 'Redenção' x Solanum habrochaites var hirsutum (PI-127826).

Estimation of genetic parameters related to the inheritance of high ZGB content in tomato leaflets was performed.

\section{MATERIAL AND METHODS}

The experiment was conducted in a greenhouse in the Horticulture Sector of the Agronomy Department of the Midwest State University, in Guarapuava, PR, Brazil (25 41'12"S latitude and $51^{\circ} 38^{\prime} 45^{\prime \prime} \mathrm{W}$ longitude, mean altitude $1100 \mathrm{~m}$ ). Plants of $F_{1}$ and $F_{2}$ generations were obtained from the interspecific cross between Solanum lycopersicum 'Redenção' x Solanum habrochaites var. hirsutum (PI-127826 accession). Redenção is a commercial cultivar that was developed by the Pernambuco Agronomic Institute - IPA for industrial processing, which is resistant to geminivirus and tospovirus (Ferraz et al., 2003). PI-127826 is a wild accession with a high ZGB content in its leaflets, which confers resistance to pests.

In a greenhouse, 553 plants were cultivated, including $433 F_{2}$ plants, $40 F_{1}$ plants, 40 'Redenção' plants, and 40 Solanum habrochaites var. hirsutum PI-127826 accession plants. The 
plants were kept in 10- $\mathrm{dm}^{3}$ pots containing a 1:1 mix of commercial substratum and soil, and fertilized with N-P-K fertilizer in a 04-14-08 formulation and limestone, according to recommendations from the 100 bulletin (Raij et al., 1997) with daily irrigation.

A colorimetric assessment was carried out in the laboratory 35 days after transplantation to pots to quantify the ZGB content present in leaflets, according to methodology proposed by Freitas et al. (2000), based on the absorbance of leaflet extract in a UV visible spectrophotometer model UV-1601 (Shimadzu Corporation, Japan) at a wavelength of $270 \mathrm{~nm}$. According to Freitas et al. (2000), absorbance is related to the amount of ZGB in the extract and this method is highly correlated to ZGB patterns obtained through high performance liquid chromatography. Based on absorbance values, plants with different ZGB levels were selected for submission to Tuta absoluta resistance tests. ZGB quantification was based on samples of six leaflet discs collected in triplicate from the upper third of each plant.

\section{Genetic parameters of the zingiberene content}

The means and variance of ZGB content of S. lycopersicum 'Redenção', S. habrochaites var hirsutum PI-127826, F1 and F2 generations were calculated and used to estimate the following parameters according to the methods described by Ramalho et al. (1993): genetic variance $(\sigma)$, environmental variance $(\sigma)$, (i.e., the variance of the 'Redenção' cultivar), and broad sense heritability $\left(\mathrm{h}^{2}\right)$. The main parameters were estimated following the methodology described by Mather and Jinks (1984), which uses the weighted minimum square method where the inverse ratio of the variance of the mean of each population serves as the weight. The parameters $\mathrm{m},[\mathrm{a}]$, and [d] were estimated from the available population means (parents, $F_{1}$ and $F_{2}$ ). The chi-square test was conducted to validate the genetic model assumed. In the case of non-rejection of the model, the medium degree of dominance (MDD) was estimated: MDD = [d] / [a], in which:

$$
h^{2}=\frac{\sigma_{g}^{2}}{\sigma^{2}}
$$

where $h^{2}=$ heritability in the broad sense; $\sigma_{g}^{2}=$ genetic variance between genotype means; $\sigma_{f}^{2}=$ phenotypic variance in $\mathrm{F}_{2}$ generation; $\sigma_{g}^{2} \sigma_{f}^{2}-\sigma_{E}^{2}$.

The environmental variance $\left(\sigma_{E}^{2}\right)$ was considered as being the variance of the Redenção cultivar $\left(\sigma_{E}^{2}=\sigma_{P 1}^{2}\right)$ due it is a lineage of autogamous plant.

The components of the means were estimated according to the methodology used by Mather and Jinks (1984) using the weighted minimum square method where the inverse ratio of the variance of the mean of each population serves as the weight. This method involves estimating the $\mathrm{m},[\mathrm{a}]$ and $[\mathrm{d}]$ parameters, from the means of populations available.

$$
\begin{array}{ll}
\overline{P_{1}}=m-[a] & (\text { Equation 2) } \\
\bar{P}_{2}=m+[a] & (\text { Equation 3) } \\
\bar{F}_{1}=m+[d] & (\text { Equation 4) } \\
\bar{F}_{2}=m+\frac{[d]}{2} & \text { (Equation 5) }
\end{array}
$$

where: $m$ = means of the parental genotypes; $[a]=$ weighted sum of additive effects; $[d]=$ weighted sum of dominance effects. 
Such estimates were used to calculate the expected value of each population, and the chisquare $\left(x^{2}\right)$ test was carried out to determine the validity of the additive-dominant genetic model,. Burton (1951) expressions were used to assess the number of genes $(n)$ involved in controlling the ZGB content in leaflets:

$$
\begin{gathered}
h=\frac{\overline{F_{1}}-\overline{P_{1}}}{\overline{P_{2}}-\overline{P_{1}}} \\
D=\overline{P_{2}}-\overline{P_{1}} \\
n=\frac{\frac{1}{4}\left(\frac{3}{4}-h+h^{2}\right) D^{2}}{\sigma_{\mathrm{f}}^{2}-\sigma_{\mathrm{E}}^{2}}
\end{gathered}
$$

Analyses were carried out with support from the GENES (Cruz, 2013) genetics and statistics computer software.

\section{Bioassays of the selected genotypes against the South American tomato moth (Tuta absoluta)}

Responses of the genotypes selected to compare ZGB content were used to assess South American tomato moth infestation. A population of Tuta absoluta was previously established in cages $(1.0 \times 1.0 \times 1.20 \mathrm{~m}$ in size, lined with anti-aphid screen), containing tomato plants of the Santa Clara cultivar, which are susceptible to the tomato moth, inside a greenhouse. Along with the parents and plants from the $F_{1}$ population, nine selected genotypes of the $F_{2}$ generation with different levels of ZGB were cloned and conditioned in cages infested with the pest. Before the beginning of the test, the sex of adult tomato-moths was identified in the laboratory (Coelho and França, 1987) and the infestation was performed with a 1:32 male/female ratio per plant (Haji et al., 1988), totaling 12 males and 16 females in each cage. A random block design was used, with 12 treatments and three repetitions, and each cage considered a block, thus totaling 36 plots, each represented by a vase with a plant. After 10 days of infestation, an initial evaluation was carried out, in which leaves from the upper third of each plant were randomly collected. Eggs and caterpillars in the abaxial face of each leaf were counted under a stereoscopic microscope. The evaluation was repeated 30 and 50 days after infestation. Genotypes were assessed on the same dates as the oviposition and caterpillar count assessments, according to a note scale proposed by Barbosa and Maluf (1996) regarding the damage caused to each plant by global parameters i.e., plant damages (PD), lesions type (LT), and percentage of attacked leaflets (PAL).

Data were submitted to analysis of variance and the means were grouped through the Scott-Knott test. Pearson correlations were estimated to verify an association between ZGB content and plant resistance. The significance of correlations was calculated through Student $t$-test. Contrasts between parents and genotype groups with contrasting ZGB contents were estimated. The SISVAR software (Ferreira, 2008) was utilized for this analysis. 


\section{RESULTS AND DISCUSSION}

Among $F_{2}$ plants, nine genotypes were selected with contrasting ZGB contents in their leaflets, six genotypes with high ZGB content (RVTZ pl\#79; RVTZ pl\#141; RVTZ pl\#142; RVTZ pl\#143; RVTZ pl\#277, and RVTZ pl\#331), and three genotypes with low content (RVTZ pl\#09; RVTZ pl\#189 and RVTZ pl\#365). Estimates of broad sense heritability $\left(h^{2}\right)$ of the ZGB contents were $81.9 \%$ (Table 1). High heritability indicates that most of the variation among $F_{2}$ plants is due to genetics, suggesting the possibility of gains by selecting individuals with high content of ZGB in segregating populations.

Table 1. Estimates of genetic parameters for the average zingiberene content in leaflets of the $F_{2}$ generation of tomato plants from the cross between S. Iycopersicum cultivar Redenção x S. habrochaites var hirsutum accession PI-127826.

\begin{tabular}{lc}
\hline Parameter & Estimate \\
\hline Phenotypic variance & 0.01682 \\
Environmental variance & 0.00303 \\
Genotypic variance & 0.01379 \\
Broad-sense heritability (\%) & 81.9 \\
Number of genes & 2.2 \\
\hline
\end{tabular}

High heritability values are commonly estimated for allelochemical contents in plants from interspecific crosses, as reported by Baier et al., (2015) for acylsugar $\left(h^{2}=81.8 \%\right)$, by Freitas (2002) for ZGB ( $h^{2}=67.8 \%$ ), and Barbosa and Maluf (1996) for 2-tridecanone $\left(h^{2}=60 \%\right)$.

The level of ZGB in leaflets was estimated to be controlled by two genes (Table 1). On the other hand, Freitas (2002), after studying this character in fresh tomato, estimated that the ZGB content is under monogenic control. The results of the $x^{2}$ test (Table 2) for ZGB content were not significant $(P>0.01)$, indicating that the additive-dominant model of the genic effects involved in controlling the ZGB content was accepted.

Table 2. Estimates of mean components of zingiberene content from interspecific tomato crossing S. lycopersicum cultivar Redenção x S. habrochaites var hirsutum accession PI-127826.

\begin{tabular}{lccc}
\hline Generation & Mean (observed) & Mean (estimated) & Deviation \\
\hline Redenção & 0.163 & 0.179 & 0.016 \\
$\mathrm{Pl}-127826$ & 1.095 & 1.008 & 0.087 \\
$\mathrm{~F}_{1}$ & 0.232 & 0.246 & 0.014 \\
$\mathrm{~F}_{2}$ & 0.306 & 0.278 & 0.028 \\
$\mathrm{M}$ & & 0.5935 & -0.3535 \\
{$[\mathrm{~d}]$} & & 0.4145 & -0.85 \\
{$[\mathrm{a}]$} & & & $0.01^{\text {ns }}$ \\
Mean degree of dominance (MDD) & & & \\
$X^{2}$ & & &
\end{tabular}

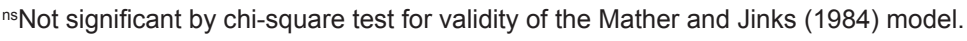

The mean degree of dominance (MDD) was -0.85 (Table 2), indicating that partial or incomplete dominance occurs in the sense of low ZGB content. The negative value points out that the presence of the recessive alleles in $S$. habrochaites var hirsutum are responsible for the high ZGB content is controlled by two genes with partial dominance in the sense of lower content. As found for heritability, the MDD is consistent with the values found by Freitas (2002), who observed a GMD of 0.66. Such a result explains the predominance of plants with low ZGB content in the $F_{2}$ generation, which is caused by the dominance of alleles that are responsible for such a phenotype. 
Genetic gains relative to arthropod-pest resistance in breeding programs that aim to develop resistant tomato cultivars can be expected when high ZGB is selected for, since heritability for high ZGB content was high (81.9\%). Genotypes selected for having a high ZGB content presented oviposition means and caterpillar counts in tomato leaflets that did not differ from those found for the $\mathrm{Pl}-127826$ accession, proving that these genotypes were resistant to the moth, which was also confirmed by the C2 contrast (Table 3). The C5 contrast (Table 3) confirmed that there were significant differences between the genotypes selected for low mean ZGB content and the 'Redenção' cultivar, providing evidence of the susceptibility of such genotypes (which presented higher caterpillar and egg counts on the surface of the leaflets) to the pest.

Table 3. Estimates of contrasts comparing the mean number of eggs and mean number of Tuta absoluta caterpillars between parents and groups of genotypes with contrasting ZGB contents at 10,30 , and 50 days after infestation.

\begin{tabular}{|c|c|c|c|c|c|c|}
\hline \multirow[t]{3}{*}{ Contrast } & \multicolumn{6}{|c|}{ Evaluation } \\
\hline & \multicolumn{3}{|c|}{ Number of eggs } & \multicolumn{3}{|c|}{ Number of caterpillar } \\
\hline & 10 days & 30 days & 50 days & 10 days & 30 days & 50 days \\
\hline C1 - high ZGB genotypes vs low ZGB genotypes & $-6.55^{\star}$ & $-11.39^{*}$ & $-10.11^{*}$ & $-10.22^{*}$ & $-7.39^{*}$ & $-6.22^{*}$ \\
\hline C2 - PI-127826 vs high ZGB genotypes & -1.56 & -1.39 & -0.56 & $-3.66^{*}$ & -0.61 & $-1.67^{*}$ \\
\hline C3 - PI-127826 vs low ZGB genotypes & $-8.11^{*}$ & $-12.78^{*}$ & $-10.67^{\star}$ & $-18.88^{*}$ & $-8.00^{*}$ & $-7.89^{\star}$ \\
\hline C4 - Redenção vs high ZGB genotypes & $10.11^{*}$ & $8.61^{*}$ & $15.11^{*}$ & $14.33^{*}$ & $6.38^{*}$ & $8.67^{\star}$ \\
\hline C5 - Redenção vs low ZGB genotypes & 3.55 & -2.78 & 5.00 & 4.11 & -1.00 & 2.44 \\
\hline
\end{tabular}

Zingiberene content at $270 \mathrm{~nm}$. ${ }^{*}$ Significant based on the Student $t$-test $(P<0.05)$.

Selection for high ZGB content has been shown to be an efficient way of obtaining plants resistant to the South American tomato moth, since genotypes with high allelochemical content maintained low oviposition and reduced caterpillar count in their leaflets. Genotypes selected for having high ZGB content presented caterpillar and egg counts that were inferior to those presented by genotypes with low ZGB content and similar to those of the wild accession, as demonstrated by the $\mathrm{C} 1$ and $\mathrm{C} 2$ contrasts (Table 3).

Evaluation of $F_{1}$ plants revealed mean caterpillar counts and oviposition that were intermediary to those found in the high and low ZGB genotypes (Table 4). All the genotypes selected for high ZGB content had the highest resistance to oviposition and lowest tomato moth caterpillar count, since they all presented means that did not differ significantly from that of Pl-127826. Significant differences between the evaluated genotypes were found for notes attributed to plant damages (PD), lesion type (LT), and percentage of attacked leaflets (PAL) (Table 5). Estimated values of the correlations between the means of oviposition and caterpillar count and the ZGB content were significant and negative. Genotypes selected for having a high ZGB content presented the lowest oviposition and caterpillar count, and highest resistance to the tomato moth (Table 4).

In the PD evaluation, as for LT and PAL, genotypes selected for high ZGB content presented resistance to pests, and the means did not differ significantly from that observed for the PI-127826 accession, as confirmed by the C2 contrast (Table 5). The C5 contrast (Table 4) demonstrates that there are no significant differences between selected genotypes for low ZGB content and the Redenção cultivar, or in the $F_{1}$ plants, which show greater susceptibility to the tomato moth when compared to genotypes that have a high allelochemical content.

The C1 contrast (Table 6) shows that the mean values for PD, LT, and PAL of genotypes that have a high ZGB content were lower than those of the genotypes selected for having a low ZGB content, confirming that resistance is promoted by the level of this allelochemical on the leaf surface. 
Table 4. Number of Tuta absoluta eggs and caterpillars at 10,30 , and 50 days after infestation of parentals, $F_{1}$, and selected genotypes from the $F_{2}$ generation of interspecific tomato crossing of $S$. lycopersicum cultivar Redenção $x$ S. habrochaites var hirsutum (PI-127826).

\begin{tabular}{|c|c|c|c|c|c|c|c|c|c|c|c|c|c|}
\hline \multirow{4}{*}{$\begin{array}{l}\text { Genotype } \\
\mathrm{PI} 127826\end{array}$} & \multirow{4}{*}{$\begin{array}{c}\text { Zingiberene } \\
\text { content }(270 \mathrm{~nm}) \\
1.099\end{array}$} & \multicolumn{12}{|c|}{ Evaluation } \\
\hline & & \multicolumn{6}{|c|}{ Number of eggs } & \multicolumn{6}{|c|}{ Number of caterpillar } \\
\hline & & \multicolumn{2}{|c|}{10 days } & \multicolumn{2}{|c|}{30 days } & \multicolumn{2}{|c|}{50 days } & \multicolumn{2}{|c|}{10 days } & \multicolumn{2}{|c|}{30 days } & \multicolumn{2}{|c|}{50 days } \\
\hline & & 0.00 & A & 1.33 & $\mathrm{a}$ & 1.66 & a & 0.00 & a & 0.66 & a & 0.00 & $\mathrm{a}$ \\
\hline RVTZ pl\#79 (high) & 0.715 & 2.00 & A & 3.66 & $\mathrm{a}$ & 1.33 & $a$ & 5.00 & a & 2.33 & a & 1.33 & a \\
\hline RVTZ pl\#141 (high) & 0.719 & 2.00 & A & 1.66 & $\mathrm{a}$ & 1.66 & a & 4.66 & a & 1.66 & a & 1.33 & a \\
\hline RVTZ pl\#142 (high) & 0.813 & 1.00 & $A$ & 2.00 & $\mathrm{a}$ & 1.00 & a & 2.66 & a & 1.00 & a & 1.33 & a \\
\hline RVTZ pl\#143 (high) & 0.592 & 2.33 & $A$ & 2.00 & a & 2.66 & a & 3.66 & a & 0.33 & a & 2.66 & a \\
\hline RVTZ pl\#277 (high) & 0.747 & 2.00 & $\mathrm{a}$ & 3.66 & $\mathrm{a}$ & 3.66 & $\mathrm{a}$ & 2.33 & a & 1.33 & a & 1.33 & a \\
\hline RVTZ pl\#331 (high) & 0.746 & 0.00 & $\mathrm{a}$ & 3.33 & a & 3.00 & a & 3.66 & a & 1.00 & a & 2.00 & a \\
\hline RVTZ pl\#09 (low) & 0.247 & 9.66 & $\mathrm{c}$ & 13.66 & $\mathrm{~b}$ & 11.00 & $\mathrm{~b}$ & 15.66 & $\mathrm{~b}$ & 8.33 & c & 5.66 & $\mathrm{~b}$ \\
\hline RVTZ pl\#189 (low) & 0.263 & 6.66 & $\mathrm{~b}$ & 17.66 & c & 14.33 & c & 13.33 & $\mathrm{~b}$ & 10.66 & d & 10.33 & c \\
\hline RVTZ pl\#365 (low) & 0.210 & 8.00 & $\mathrm{~b}$ & 11.00 & $b$ & 11.66 & $\mathrm{~b}$ & 12.66 & $\mathrm{~b}$ & 7.00 & c & 7.66 & $b$ \\
\hline Redenção & 0.084 & 11.66 & $\mathrm{c}$ & 11.33 & $\mathrm{~b}$ & 17.33 & c & 18.00 & $\mathrm{~b}$ & 7.66 & c & 10.33 & $c$ \\
\hline $\mathrm{F}_{1}$ & 0.145 & 6.33 & $\mathrm{~b}$ & 7.33 & a & 8.33 & $\mathrm{~b}$ & 9.33 & $\mathrm{~b}$ & 4.66 & $\mathrm{~b}$ & 6.00 & $\mathrm{~b}$ \\
\hline Linear Correlation & & $-0.92^{*}$ & & $-0.81^{*}$ & & $-0.88^{*}$ & & $-0.92^{*}$ & & $-0.83^{*}$ & & $-0.90^{*}$ & \\
\hline
\end{tabular}

Means followed by the same letter do not differ from each other according to the Scott-Knott test $(P<0.05)$. *Significant based on the Student $t$-test $(P<0.05)$.

Table 5. Means values relating to plant damage (PD), lesions type (LT), and percentage of attacked leaflets (PAL) at 10,30 , and 50 days after Tua absoluta infestation of parentals, $F_{1}$, and selected genotypes from the $F_{2}$ generation of an interspecific tomato cross of S. lycopersicum cultivar Redenção x S. habrochaites var hirsutum (PI-127826).

\begin{tabular}{|c|c|c|c|c|c|c|c|c|c|c|c|c|c|c|c|c|c|c|c|}
\hline \multirow{4}{*}{$\begin{array}{l}\text { Genotype } \\
\\
\mathrm{Pl} 127826\end{array}$} & \multirow{4}{*}{$\begin{array}{c}\text { Zingiberene } \\
\text { content }(270 \mathrm{~nm}) \\
1.099\end{array}$} & \multicolumn{18}{|c|}{ Evaluation } \\
\hline & & \multicolumn{6}{|c|}{ Plant damage (PD) } & \multicolumn{6}{|c|}{ Lesions type (LT) } & \multicolumn{6}{|c|}{ Percentage of attacked leaflets (PAL) } \\
\hline & & \multicolumn{2}{|c|}{10 days } & \multicolumn{2}{|c|}{30 days } & \multicolumn{2}{|c|}{50 days } & \multicolumn{2}{|c|}{10 days } & \multicolumn{2}{|c|}{30 days } & \multicolumn{2}{|c|}{50 days } & \multicolumn{2}{|c|}{10 days } & \multicolumn{2}{|c|}{30 days } & \multicolumn{2}{|c|}{50 days } \\
\hline & & 0.00 & a & 2.00 & A & 2.66 & $a$ & 0.00 & $\mathrm{a}$ & 1.77 & A & 1.77 & a & 0.00 & $a$ & 1.88 & a & 2.44 & $a$ \\
\hline RVTZ pl\#79 (high) & 0.715 & 1.00 & $\mathrm{~b}$ & 2.22 & A & 3.00 & a & 1.00 & $\mathrm{~b}$ & 2.00 & A & 2.11 & a & 1.22 & $\mathrm{~b}$ & 2.33 & a & 2.88 & a \\
\hline RVTZ pl\#141 (high) & 0.719 & 1.11 & $\mathrm{~b}$ & 2.22 & A & 2.88 & $a$ & 1.11 & $\mathrm{~b}$ & 2.11 & A & 2.66 & b & 1.44 & $\mathrm{~b}$ & 2.77 & $\mathrm{~b}$ & 2.66 & a \\
\hline RVTZ pl\#142 (high) & 0.813 & 1.00 & $\mathrm{~b}$ & 2.00 & $A$ & 2.66 & a & 1.11 & $\mathrm{~b}$ & 2.22 & A & 2.00 & a & 1.11 & $\mathrm{~b}$ & 2.00 & a & 2.44 & a \\
\hline RVTZ pl\#143 (high) & 0.592 & 1.00 & $\mathrm{~b}$ & 2.22 & A & 3.00 & a & 1.00 & $\mathrm{~b}$ & 2.00 & A & 2.88 & $\mathrm{~b}$ & 1.00 & $b$ & 2.66 & $\mathrm{~b}$ & 3.11 & a \\
\hline RVTZ pl\#277 (high) & 0.747 & 0.88 & $\mathrm{~b}$ & 2.22 & $A$ & 2.55 & a & 1.00 & $\mathrm{~b}$ & 1.88 & A & 2.66 & $b$ & 0.88 & $\mathrm{~b}$ & 2.88 & $\mathrm{~b}$ & 2.55 & a \\
\hline RVTZ pl\#331 (high) & 0.746 & 1.11 & $\mathrm{~b}$ & 2.00 & $A$ & 3.00 & $a$ & 1.33 & $\mathrm{~b}$ & 2.00 & $A$ & 2.44 & $\mathrm{~b}$ & 1.55 & $\mathrm{~b}$ & 2.66 & $\mathrm{~b}$ & 2.66 & $a$ \\
\hline RVTZ pI\#09 (low) & 0.247 & 1.77 & $\mathrm{c}$ & 3.55 & B & 4.11 & $\mathrm{~b}$ & 2.11 & $\mathrm{c}$ & 2.88 & B & 4.22 & $\mathrm{c}$ & 1.88 & c & 3.77 & $\mathrm{c}$ & 4.22 & $\mathrm{~b}$ \\
\hline RVTZ pl\#189 (low) & 0.263 & 2.11 & $\mathrm{c}$ & 4.33 & C & 5.00 & c & 2.11 & $\mathrm{c}$ & 4.33 & C & 5.00 & $d$ & 2.11 & c & 4.66 & $\mathrm{c}$ & 5.00 & $\mathrm{c}$ \\
\hline RVTZ pl\#365 (low) & 0.210 & 2.55 & $\mathrm{c}$ & 4.22 & C & 4.22 & $\mathrm{~b}$ & 1.77 & $\mathrm{c}$ & 3.44 & B & 4.66 & $\mathrm{~d}$ & 1.88 & c & 4.22 & c & 4.22 & $\mathrm{~b}$ \\
\hline Redenção & 0.084 & 2.44 & $\mathrm{c}$ & 4.22 & C & 5.00 & c & 2.55 & $\mathrm{c}$ & 4.22 & C & 5.00 & d & 2.33 & c & 4.55 & c & 5.00 & c \\
\hline $\mathrm{F}_{1}$ & 0.145 & 2.11 & c & 2.77 & A & 3.88 & $\mathrm{~b}$ & 2.33 & $\mathrm{c}$ & 3.08 & B & 3.55 & $\mathrm{c}$ & 2.66 & c & 3.22 & $\mathrm{~b}$ & 3.88 & b \\
\hline Correlations & & $-0.96^{*}$ & & $-0.84^{*}$ & & $-0.89^{*}$ & & $-0.95^{\star}$ & & $-0.85^{\star}$ & & $-0.91^{*}$ & & $-0.91^{*}$ & & $-0.88^{*}$ & & $-0.91^{\star}$ & \\
\hline
\end{tabular}

Means followed by the same letter do not differ from each other according to Scott-Knott test $(P<0.05)$. ${ }^{*}$ Significant based on the Student $t$-test $(P<0.05)$.

The $F_{1}$ plants presented mean PD and PAL levels that were similar to those observed in the genotypes with high ZGB content only when evaluated 30 days after infestation. In addition, the presence of the allelochemical, even at low levels, repelled the tomato moth (Table 6). Among the genotypes with high ZGB content, RVTZ pl\#79 and RVTZ pl\#142 stood out as having higher resistance to the tomato moth, since their means did not differ from that of the $\mathrm{Pl}-127826$ accession in all evaluations. 
Table 6. Estimates of contrasts comparing the mean values of plant damage (PD), lesions type (LT), and percentage of attacked leaflets (PAL) between parents and groups of genotypes with difference ZGB contents at 10, 30 , and 50 days after infestation.

\begin{tabular}{|c|c|c|c|c|c|c|c|c|c|}
\hline \multirow[t]{3}{*}{ Contrast } & \multicolumn{9}{|c|}{ Evaluation } \\
\hline & \multicolumn{3}{|c|}{ Plant damages (PD) } & \multicolumn{3}{|c|}{ Lesions type (LT) } & \multicolumn{3}{|c|}{$\begin{array}{c}\text { Percentage of attacked } \\
\text { leaflets (PAL) }\end{array}$} \\
\hline & 10 days & 30 days & 50 days & 10 days & 30 days & 50 days & 10 days & 30 days & 50 days \\
\hline C1 - high ZGB genotypes vs low ZGB genotypes & $-1.13^{*}$ & $-1.89^{*}$ & $-1.59^{*}$ & $-0.91^{*}$ & $-1.52^{*}$ & $-2.17^{*}$ & $-0.76^{*}$ & $-1.67^{*}$ & $-1.76^{*}$ \\
\hline C2 - PI-127826 vs high ZGB genotypes & $-1.02^{*}$ & -0.15 & -0.19 & $1.09^{*}$ & $-0.26^{*}$ & $-0.68^{*}$ & $-1.20^{*}$ & $-0.67^{*}$ & -0.28 \\
\hline C3 - PI-127826 vs low ZGB genotypes & $-2.15^{\star}$ & $-2.04^{*}$ & $1.78^{\star}$ & $-1.99^{*}$ & $-1.78^{*}$ & $-2.85^{\star}$ & $-1.96^{*}$ & $-2.33^{*}$ & $-2.04^{*}$ \\
\hline C4 - Redenção vs high ZGB genotypes & $1.43^{\star}$ & $2.07^{*}$ & $2.15^{\star}$ & $1.46^{*}$ & $2.18^{*}$ & $2.54^{*}$ & $1.13^{*}$ & $2.00^{*}$ & $2.28^{*}$ \\
\hline C5 - Redenção vs low ZGB genotypes & 0.30 & 0.18 & 0.56 & $0.55^{*}$ & $0.67^{*}$ & 0.37 & $0.37^{\star}$ & 0.33 & 0.52 \\
\hline
\end{tabular}

*Significant based on the Student $t$-test $(\mathrm{P}<0.05)$.

Researchers have associated high ZGB levels with resistance to the tomato moth (Tuta absoluta), which confirms the results found in this study (Azevedo et al., 2003; Silva, 2009; Oliveira et al., 2012). High levels of ZGB are efficient at causing resistance to the tomato moth when compared to genotypes that have low levels of ZGB.

It is therefore concluded that inheritance of the ZGB level in tomato leaflets from the interspecific cross between Solanum lycopersicum 'Redenção' x Solanum habrochaites var. hirsutum (PI-127826 accession) is controlled by two genes with partial dominance in the sense of lower content, presenting higher broad sense heritability (81,9\%). Furthermore, selection of high ZGB content genotypes is an efficient way to obtain plants that are resistant to the South American tomato moth.

\section{Conflicts of interest}

The authors declare they have no conflict of interest.

\section{ACKNOWLEDGMENTS}

The authors thank the Araucária Foundation for Support for Scientific and Technological Development of Paraná for financial support, CNPq and CAPES for scholarship concessions and FINEP for financial support.

\section{REFERENCES}

Azevedo SM, Faria MV, Maluf WR, de Oliveira ACB, et al. (2003). Zingiberene-mediated resistance to the South American tomato pinworm derived from Lycopersicon hirsutum var. hirsutum. Euphytica 134: 347-351.

Baier JE, Resende JT, Faria MV, Schwarz K, et al. (2015). Indirect selection of industrial tomato genotypes that are resistant to spider mite (Tetranychus urticae). Genet. Mol. Res. 14: 244-252.

Barbosa LV and Maluf WR (1996). Heritability of 2-tridecanone mediated arthropod resistance in an interspecific segregating generation of tomato. Rev. Bras. Genet. 19: 465-468.

Burton GW (1951). Quantitative inheritance of pearl millet (Pennisectum glaucum). Agron. J. 43: 409-416.

Clemente FMVT and Boiteux LS (2012). Produção de tomate para processamento industrial. Embrapa, Brasília.

Coelho MCF and França FH (1987). Biologia e quetotaxia da larva e descrição da pupa e adulto da traça-do-tomateiro. Pesq. Agropec. Bras. 22: 129-135.

Cruz CD (2013). GENES - A software package for analysis in experimental statistics and quantitative genetics. Acta Sci. 35 : 271-276. 
Dias DM, Resende JT, Faria MV, Camargo LK, et al. (2013). Selection of processing tomato genotypes with high acyl sugar content that are resistant to the tomato pinworm. Genet. Mol. Res. 12: 381-389.

FAEG (Custos de produção tomate industrial). Available at [http://sistemafaeg.com.br/mercados-e-cotacoes/outros/custo-deproducao?acao=custoProducao]. Accessed November 11, 2013.

Ferraz E, Resende LV, Lima GSA and Silva MCL (2003). Redenção: nova cultivar de tomate para a indústria resistente a geminivírus e tospovírus. Hortic. Bras. 21: 578-580.

Ferreira D (2008). SISVAR: um programa para análises e ensino de estatística. Symposyum, Lavras, 6: 36-41.

Freitas JA de, Maluf WR, Cardoso M das G and Benites FRG (2000). Métodos para a quantificação do zingibereno em tomateiro, visando à seleção indireta de plantas resistentes a artrópodes-praga. Acta Sci. 22: 943-949.

Freitas JA, Maluf WR, Cardoso MG, Gomes LAA, et al (2002). Inheritance of foliar zingiberene contents and their relationship to trichome densities and whitefly resistance in tomatoes. Euphytica 127: 275-287.

Gonçalves LD, Maluf WR, Cardoso M das G, Resende JTV de, et al. (2006). Relação entre zingibereno, tricomas foliares e repelência de tomateiros a Tetranychusevansi. Pesq. Agropec. Bras. 41: 267-273.

Haji FNP, Parra JRP, Silva JP and Batista JG de S (1988). Biologia da traça-do-tomateiro sob condições de laboratório. Pesq. Agropec. Bras. 23: 107-110.

Lucini T, Faria MV, Rohde C, Resende JTV, et al. (2015). Acylsugar and the role of trichomes in tomato genotypes resistance to Tetranychus urticae. Arthropod Plant Interact. 9: 45-53.

Maluf WR, Inoue IF, Ferreira R, Gomes LAA, et al. (2007). Higher glandular trichome density in tomato leaflets and repellence to spider mites. Pesq. Agropec. Bras. 42: 1227-1235.

Mather K and Jinks JL (1984). Introdução à Genética Biométrica. Sociedade Brasileira de Genética, Ribeirão Preto, SP, Brasil.

Neiva IP, Andrade Júnior VC, Maluf WR, Oliveira CM, et al. (2013). Role of allelochemicals and trichome density in the Resistance of tomato to whitefly. Cienc. Agrotec. 37: 61-67.

Oliveira CM, Andrade Junior VC, Maluf WR, Neiva IP, et al. (2012). Resistance of tomato strains to the moth tutaabsoluta imparted by allelochemicals and trichome density. Cienc. Agrotec. 36: 45-52.

Ramalho MAP, Santos JB and Zimmerman MJ (1993). Genética quantitativa em plantas autógamas. UFG, Goiânia, MG, Brasil.

Raij BV, Cantarella H, Quaggio JA and Furlani AMC (1996). Boletim Técnico 100: Recomendações de Adubação e Calagem para o Estado de São Paulo. Campinas.

Resende JTV de, Maluf WR, Cardoso M das G, Gonçalves LD, et al. (2009). Resistance of tomato genotypes to the silverleaf whitefly mediated by acylsugars. Hortic. Bras. 27: 345-348.

Silva AC and Carvalho GA (2004). Manejo integrado de pragas. In: Tomate: produção em campo, em casa-de-vegetaçao e em hidroponia (Alvarenga AR, ed.). Editora UFLA, Lavras, 309-366.

Silva VF, Maluf WR, Cardoso MG, Gonçalves Neto AC, et al. (2009). Resistência mediada por aleloquímicos de genótipos de tomateiro à mosca-branca e ao ácaro-rajado. Pesq. Agropec. Bras. 44: 1262-1269.

Suinaga FA, Casali VWD, Silva DJH and Picanço MC (2003). Dissimilaridade genética de fontes de resistência de Lycopersicon spp. a Tuta absoluta 1 (Meyrick, 1917) (Lepidoptera: Gelechidae). Rev. Bras. Agrocienc. 9: 371-376. 